\title{
PENGARUH ASAP ANTI NYAMUK KERTAS BAKAR TERHADAP JUMLAHERITROSIT PADA MENCIT (Mus musculus L.)
}

\author{
Choirun Niswah ${ }^{1}$, Syarifah $^{2}$, Fitria Sany ${ }^{3 *}$ \\ ${ }^{1}$ Wakil Dekan III, Fakultas Ilmu Tarbiyah dan Keguruan, UIN Raden Fatah Palembang, \\ Jl. Prof. K. H. Zainal Abidin Fikri No. 1 A KM 3.5, Palembang 30126, Indonesia \\ ${ }^{2}$ Dosen Prodi Pendidikan Biologi, Fakultas Ilmu Tarbiyah dan Keguruan, UIN Raden Fatah Palembang, \\ Jl. Prof. K. H. Zainal Abidin Fikri No. 1 A KM 3.5, Palembang 30126, Indonesia \\ ${ }^{3}$ Mahasiswa Prodi Pendidikan Biologi, Fakultas Ilmu Tarbiyah dan Keguruan, UIN Raden Fatah Palembang, \\ Jl. Prof. K. H. Zainal Abidin Fikri No. 1A KM 3.5, Palembang 30126, Indonesia
}

*email: Fitria_sany@yahoo.com

Telp: +6285664652954

\begin{abstract}
Indonesia is a tropical country encountered species of mosquitoes, such as Aedes aegypti and Culex quinquefasciatus. One of the efforts made to eradicate mosquitoes is to use mosquito repellent. Mosquito repellent is one type of insect killers household pesticide (insecticide) containing dangerous transfultrin. This study aims to determine the effect of anti-mosquito smoke burn paper against the number of erythrocytes in mice (Mus musculus L.). The study was conducted in September 2016 in the Laboratory of Mathematics of Tarbiyah and Teaching Faculty of UIN Raden Fatah Palembang. The research method using a completely randomized design (CRD) with treatment P0 (without exposure to insect repellent), P1 (anti mosquito burn paper, 2 hours / day), P2 (anti mosquito burn paper, 4 hours / day), P3 (anti mosquito burn paper, 6 hours / day) each with 6 replications, for 20 days. On the last day to do the stabbing in the tail to draw blood, were calculated against the number of red blood cells (erythrocytes) by using Haemocytometer. The results showed that exposure to fuel anti-mosquito burn paper affect the red blood cells of mice that P1 (anti mosquito burn paper, 2 hours / day) with an average of $8,72 \times 10^{6} / \mathrm{mL}$ blood, P2 (anti mosquito burn paper, 4 hours / day) with an average of $8,87 \times 10^{6} /$ $\mathrm{mL}$ blood, P3 (anti mosquito burn paper, 6 hours / day) with an average of 7,89 x $10^{6} / \mathrm{mL}$ of blood. Effect of anti-mosquito smoke burn the most significant papers in a decrease in the number of erythrocytes of mice (Mus musculus L.) is 6 hours of exposure to an average of 7,89 x 10 $/ \mathrm{mL}$. The result of Anova test showed $\mathrm{F}$ count $>$ Ftable namely 7,80 > 4,40 it means the treatment has significance.
\end{abstract}

Keywords: anti mosquito burn paper, red blood cell

\section{PENDAHULUAN}

Indonesia merupakan daerah yang beriklim tropis.Hal tersebut sesuai dengan habitat bagi nyamuk untuk berkembang biak. Di Indonesia ada berbagai spesies nyamuk, diantaranya adalah Aedes aegypti dan Culex quinquefasciatus yang seringkali menimbulkan masalah kesehatan bagi masyarakat (Prastiwi 2015).

Usaha-usaha yang telah dilakukan masyarakat untuk penanggulangan nyamuk tersebut salah satunya yaitu dengan pemakaian obat anti nyamuk, yang tentunya mengandung insektisida beberapa senyawa kimia (Almahdy dkk, 2014).

Kebanyakan obat nyamuk yang beredar di Indonesia mengandung bahan d-allethrin, transflutrin, bioallethrin, pralethrin, $d$ phenothrin, cypenothrin atau esbiothrin, yang merupakan turunan dari pyrethroid (WHO, 2005). 
Pyrethroid yang masuk ke dalam tubuh secara inhalasi dalam waktu yang lama, dapat menyebabkan gangguan pada paru-paru. Menurut Arobi (2010) pada kontrol positif (perlakuan dengan dipapar allethrin tanpa pemberian jahe merah) terjadi proliferasi dan penebalan alveolus paru-paru tikus sampai terjadi kanker. Selain itu phyrethroid juga mengakibatkan iritasi kulit seperti pedih, rasa terbakar, gatal-gatal (Raini, 2007), iritasi mata, dan asma, serta menyebabkan hati tidak mampu untuk melakukan detoksifikasi secara sempurna. Akibat lain dari phyretroid munculnya metabolit sekunder yang dapat bertindak sebagai radikal bebas, selanjutnya radikal bebas ini mengikuti peredaran darah menuju keseluruh tubuh (Elia dkk, 2015).

Adanya radikal bebas dalam darah akan berdampak bagi fisiologis tubuh. Di dalam eritrosit radikal bebas yang paling banyak adalah radikal bebas oksigen (misalnya superoksida, hidroksil radikal, hidrogen peroksida) yang dapat merusak komponen biokimia sel seperti asam deoksiribunukleat (DNA), asam ribonukleat (RNA), karbohidrat, lemak, protein dan mikronutrien (vitamin dan mineral) (Sundaryono, 2011).

Penelitian terdahulu dilakukan oleh Prastiwi (2015) yang menyatakan pada obat nyamuk bakar coil yang mengandung bahan aktif $d$-allethrin dan transflutrin, yaitu masingmasing sebesar $0,1 \%$ dan $0,25 \%$. Sedangkan pada merk yang sama yaitu liquid dan aerosol masing-masing mengandung sipermetrin $0,4 \mathrm{~g} / \mathrm{l}$ dan $0,10 \%$ yang menyebabkan terjadinya hipoksia yang dialami oleh mencit selama diberi perlakuan. Hipoksia adalah kekurangan oksigen dijaringan tubuh. Hipoksia disebabkan karena kadar oksigen dalam udara sekitar ruangan mencit menurun akibat adanya asap obat nyamuk bakar maupun elektrik. Asap obat nyamuk dikategorikan sebagai salah satu sumber polusi udara di dalam ruangan Kebanyakan masyarakat tidak memperhatikan zat aktif yang terkandung dalam obat nyamuk yang digunakan.

Selain itu, Almahdy dkk (2014) dalam penelitiannya yang berjudul uji efek teratogen anti nyamuk bakar yang mengandung transfluthrin terhadap fetus mencit putih menyatakan bahwa pemaparan anti nyamuk bakar yang mengandung transfluhtrin, menyebabkan kelainan pada fetus mencit putih yaitu terjadi anencephaly yang disebabkan oleh hipertermia,sertapenurunan berat badan induk mencit dengan peresentasi berat badan dari masing-masing kelompok perlakuan yaitu, kelompok kontrol 49,89\%; kelompok 1 kali pemaparan 46,27\%; kelompok 2 kali pemaparan 45,58\%; kelompok 3 kali pemaparan 43,50\%; kelompok 4 kali pemaparan hanya memiliki persentase $39,94 \%$.

Eritrosit atau sel darah merah mengandung hemoglobin dan bertugas mengedarkan oksigen ke seluruh tubuh, dan bila tubuh mengalami kekurangan eritrosit maka orang tersebut akan menderita anemia. Transfluthrin adalah pestisida golongan pyretroid yang merupakan bagian dari insektisida organik sintetik yang sering digunakan sebagai bahan insektisida rumah tangga (Marjuki, 2009). Akumulasinya dalam tubuh dapat menyebabkan stress oksidatif. Stress oksidatif adalah kondisi keseimbangan antara oksidan dan antioksidan yang berpotensi menimbulkan kerusakan. Stres oksidatif dapat disebabkan oleh paparan sinar $\mathrm{x}$, ozon, asap rokok, pestisida, alkohol, bahan-bahan industri kimia dan polusi udara. Pyrethroid dapat menginduksi terjadinya stres oksidatif dan berpengaruh pada beberapa organ, jaringan dan sel seperti : hati, otak, ginjal dan eritrosit (Wijayanthi, 2011).

\section{METODOLOGI PENELITIAN Waktu dan Tempat}

Penelitian ini dilaksanakan di Laboratorium MIPA Universitas Islam Negeri Raden Fatah Palembang, yang berlangsung pada bulan September-Oktober 2016.

\section{Metode Penelitian}

Penelitian ini menggunakan metode eksperimen melalui Rancangan Acak Lengkap (RAL) dengan empat perlakuan (t) dan enam ulangan (r). Menurut Hanafiah, (2014) patokan jumlah ulangan dianggap telah cukup baik bila memenuhi persamaan berikut:

$$
(\mathrm{t}-1)(\mathrm{r}-1) \geq 15
$$

Hasil data yang diperoleh dianalisis secara ansira (ANOVA) dari perlakuan tanpa paparan anti nyamuk, 2 jam paparan, 4 jam paparan, dan 6 jam paparan. Perlakuan yang diberikan selama 20 hari. 


\section{Alat dan Bahan}

Alat yang digunakan untuk perlakuan adalah kandang dengan ukuran $40 \mathrm{~cm}$ x $30 \mathrm{~cm}$ $\mathrm{x} 25 \mathrm{~cm}$ dan perlengkapannya yaitu tempat makan dan minum mencit, alas kandang, dan kotak buatan yang terbuat dari triplek dengan ukuran $40 \mathrm{~cm}$ x $30 \mathrm{~cm}$ x $30 \mathrm{~cm}$ sebagai penutup kandang mencit saat diberi perlakuan. Alat untuk menghitung sel darah yaitu haemocytometer.

Bahan yang digunakan untuk perlakuan adalah anti nyamuk kertas bakar dengan kandungan transflutrin $1 \%(0,004 \mathrm{gr} / \mathrm{pcs})$ dan Mencit (Mus musculus L) jantan galur Swiss Webster (memiliki berat badan 36 sampai 39 gram dan umur 3 bulan), pakan berupa pelet ikan, air diambil dari kran di laboratorium. Bahan yang digunakan untuk menghitung sel darah merah yaitu larutan Hayem sebanyak 50 $\mathrm{ml}$ dan bahan lain yaitu alkohol $70 \%$.

\section{Cara Kerja}

Perlakuan pada Hewan Uji

Mencit diaklimatisasi di dalam kandang selama 1 minggu. Selama penelitian, mencit diberi makan sebanyak 36 gram dalam tiap kotak perlakuan dan minum $500 \mathrm{ml}$. Pada saat

\section{HASIL DAN PEMBAHASAN}

Berdasarkan penelitian yang telah dilaksanakan, yaitu pengaruh asap anti nyamuk kertas bakar terhadap jumlah eritrosit pada perlakuan, obat nyamuk kertas bakar diletakkan di atas kawat kandang mencit kemudian dibakar lalu ditutup dengan kotak buatan. Pada hari terakhir dilakukan penusukan ekor tikus dengan blood lancet untuk mengambil darah pada semua mencit selanjutnya diambil dengan pipet eritrosit, kemudian dilakukan penghitungan jumlah sel darah merah.

Pengamatan Eritrosit

Darah diambil dari ekor mencit dengan cara distusuk dengan blood lancet, kemudian ekor diusap dengan kapas beralkohol, setelah darah keluar tempelkan ujung pipet eritrosit (dengan tanda merah di dalamnya) isaplah darah sampai 0,5. Kemudian encerkan dengan larutan Hayem sampai batas 101.Ikatkan pipa karet pada pipet eritrosit dan kocok perlahanlahan dengan membentuk goyangan angka delapan. Persiapkan terlebih dahulu bilik hitung dibawah mikroskop sebelum darah diisikan pada bilik hitung. Untuk menghitung jumlah eritrosit digunakan kotak-kotak kecil di tengah yang terdapat pada kamar hitung. Eritrosit dihitung dalam 80 kotak kecil.(Santoso, 2014). Jumlah eritrosit/cc $=$ hasil yang diperoleh $\mathrm{x}$ 10.000 (Kiswari, 2014).

mencit (Mus musculus L.)dapat dilihat pada tabel berikut:

Tabel 1. Hasil Jumlah Eritrosit Mencit (Mus musculus L) dalam juta/mL

\begin{tabular}{|c|c|c|c|c|c|c|c|c|}
\hline \multirow{2}{*}{ Perlakuan (t) } & \multicolumn{5}{|c|}{ Ulangan } & \multirow[b]{2}{*}{ VVI } & \multirow{2}{*}{ Jumlah Eritrosit } & \multirow{2}{*}{$\begin{array}{c}\text { Rerata } \\
\text { (juta/mL) }\end{array}$} \\
\hline & I & II & III & IV & $\mathrm{V}$ & & & \\
\hline 0 & 1134 & 1067 & 1280 & 1057 & 1065 & 1392 & 6.995 & 1.166 \\
\hline 2 jam & 923 & 970 & 1031 & 1053 & 583 & 671 & 5.234 & 872 \\
\hline 4 jam & 792 & 1030 & 806 & 815 & 839 & 1038 & 5.320 & 887 \\
\hline $6 \mathrm{jam}$ & 956 & 765 & 763 & 516 & 803 & 930 & 4.733 & 789 \\
\hline
\end{tabular}

Berdasarkan Tabel 1. dapat terlihat bahwa jumlah eritrosit mencit (Mus musculus L.) setelah diberi perlakuan mengalami penurunan. Jumlaheritrosit yang terendah ada pada kelompok $\mathrm{P}_{3}$ (6 jam paparan anti nyamuk kertas bakar) dengan rata-rata $11,66 \times 10^{6} / \mathrm{mL}$ darah sedangkan jumlah darah yang paling banyak ada pada kelompok $\mathrm{P}_{0}$ (kontrol) yaitu $7,89 \times 10^{6} / \mathrm{mL}$ darah. Akan tetapi pada kelompok $\mathrm{P}_{1}$ (2 jam paparan anti nyamuk kertas bakar) dan $\mathrm{P}_{2}$ (4 jam paparan anti nyamuk kertas bakar)mencit juga mengalami penurunan darah masing-masing dengan rata-rata $8,72 \times 10^{6} / \mathrm{mL}$ an $8,87 \times 10^{6} / \mathrm{mL}$ darah. Artinyapemberian anti 
nyamuk kertas bakar yang sama pada semua kotak perlakuan memberi pengaruh pada jumlah eritrosit mencit (Mus musculus L.) yang mengindikasi adanya gangguan bagi fisiologis tubuh.

Terpaparnya tubuh oleh pestisida berdampak pada komponen yang ada dalam tubuh manusia, salah satunya adalah darah. Pestisida dapat menimbulkan abnormalitas pada profil darah karena pestisida dapat mengganggu organ-organ pembentuk sel-sel darah, proses pembentukan sel-sel darah dan juga sistem imun (Djau, 2009).

Eritrosit atau sel darah merah mengandung hemoglobin dan bertugas mengedarkan oksigen ke seluruh tubuh, dan bila tubuh mengalami kekurangan eritrosit maka orang tersebut akan menderita anemia. Transfluthrin adalah pestisida golongan pyretroid yang merupakan bagian dari insektisida organik sintetik yang sering digunakan sebagai bahan insektisida rumah tangga (Marjuki, 2009).

Berdasarkan Tabel 1. Kemudian dilakukan analisis sidik ragam dengan pola RAL dengan 4 perlakuan dan 6 kali ulangan. Adapun hasil analisis tersebut adalah sebagai berikut:

Tabel 2. Analisis Sidik Ragam (Ansira) RAL

\begin{tabular}{cccccc}
\hline SK & DB & JK & KT & F Hitung & F tabel 1\% \\
\hline Perlakuan & 3 & $484.432,5$ & $161.477,16$ & $7,80^{* *}$ & 4,22 \\
Galat & 20 & $475.985,34$ & $20.695,01$ & & \\
Total & 23 & $960.416,84$ & & & \\
\hline
\end{tabular}

$\mathrm{KK}=15 \%$

Keterangan:

$* *$ = berbeda sangat nyata

Berdasarkan hasil analisis data diketahui bahwa $F_{\text {hitung }}>F_{\text {tabelyaitu }}$ 7,80 $>4,22$ dinyatakan bahwa $\mathrm{H}_{1}$ diterima dan $\mathrm{H}_{0}$ ditolak, hal ini menyatakan bahwa asap anti nyamuk kertas bakar dapat mempengaruhi jumlah eritrosit mencit (Mus musculus L.). Untuk mengetahui pengaruh setiap perlakuan dilakukan uji lanjut dengan menggunakan uji Beda Jarak Nyata Duncan pada taraf $1 \%$ seperti pada tabel berikut:

Tabel 3. Uji Beda Jarak Nyata Duncan (BJND) Pengaruh Asap Anti Nyamuk Kertas Bakar Terhadap Jumlah Eritrosit Pada Mencit (Mus musculus L.)

\begin{tabular}{|c|c|c|c|c|c|}
\hline \multirow{2}{*}{ Perlakuan $(\mathrm{t})$} & \multirow{2}{*}{ Rata-rata } & \multicolumn{3}{|c|}{ Beda riel pada jarak P } & \multirow{2}{*}{ BJND 0,01} \\
\cline { 3 - 5 } & & 2 & 3 & 4 & \\
\hline $\mathrm{P}_{3}$ & 788,83 & - & & & $\mathrm{A}$ \\
\hline $\mathrm{P}_{1}$ & 872,33 & $83,5^{* *}$ & - & - & $\mathrm{B}$ \\
\hline $\mathrm{P}_{2}$ & 886,66 & $14,33^{* *}$ & $97,83^{* *}$ & - & $\mathrm{BC}$ \\
\hline $\mathrm{P}_{0}$ & $1.165,83$ & $279,17^{* *}$ & $293,5^{* *}$ & $377^{* *}$ & $\mathrm{D}$ \\
\hline $\mathrm{P}_{0,01(\mathrm{p}, 20)}$ & 4,02 & 4,22 & 4,33 & \\
\hline BJND $_{0,01(\mathrm{p}, 20)}$ & 96,36 & 101,15 & 103,79 & \\
\hline
\end{tabular}

Keterangan: angka-angka yang diikuti oleh huruf yangsama berarti berbeda tidak nyata pada taraf uji $1 \%$ ** = berbeda sangat nyata

Akumulasinya dalam tubuh dapat menyebabkan stress oksidatif. Stress oksidatif adalah kondisi keseimbangan antara oksidan dan antioksidan yang berpotensi menimbulkan kerusakan. Stres oksidatif dapat disebabkan oleh paparan sinar $\mathrm{x}$, ozon, asap rokok, pestisida, alkohol, bahan-bahan industri kimia dan polusi udara. Pyrethroid dapat menginduksi terjadinya stres oksidatif dan berpengaruh pada beberapa organ, jaringan dan sel seperti : hati, otak, ginjal dan eritrosit (Wijayanthi, 2011). 
Pengaruh pestisida dalam kadar hemoglobin dimana pestisida ini menyebabkan penurunan produksi atau peningkatan penghancuran sel darah merah. Hal ini membuat terbentuknya methemoglobin didalam sel darah merah.Hal ini menyebabkan hemoglobin menjadi tidak normal dan tidak dapat menjalankan fungsinya dalam menghantar oksigen. Kehadiran methemoglobin dalam darah akan menyebabkan penurunan kadar $\mathrm{Hb}$ di dalam sel darah merah sehingga terjadi anemia hemolitik (Ramsingh, 2010).

Paparan obat nyamuk dapat membahayakan kesehatan, asap yang dihasilkan dari pembakaran obat nyamuk akan menghasilkan radikal bebas di udara. Radikal bebas dalam jumlah berlebih di dalam tubuh sangat berbahaya karena dapat berakibat pada rusaknya sel, asam nukleat, protein dan jaringan lemak. Radikal bebas terbentuk di dalam tubuh akibat produk sampingan proses metabolisme ataupun karena tubuh terpapar radikal bebas melalui pernapasan. Bahaya radikal bebas terhadap eritrosit diantaranya adalah dengan merusak struktur membran eritrosit sehingga elastisitas membran terganggu dan mudah pecah. Hal ini dapat menyebabkan turunnya jumlah eritrosit. Peroksidasi lipid pada membran eritrosit dapat mengakibatkan hilangnya fluiditas membran dan meningkatkan fragilitas atau kerapuhan membran eritrosit yang selanjutnya mengakibatkan eritrosit akan mudah pecah atau hemolisis (Wijayanthi, 2011).

Pyrethroid sintesis dapat menyebabkan karsinogen dan toksisitas pada kulit maupun organ reproduksi. Pestisida dapat masuk ke dalam tubuh melalui kulit (dermal), pernafasan (inhalasi), atau mulut (oral). Pestisida akan segera diabsorbsi jika kontak melalui kulit atau mata. Absorpsi ini akan terus berlangsung selama pestisida masih ada pada kulit. Kecepatan absorpsi berbeda pada setiap bagian tubuh. Perpindahan residu pestisida dari suatu bagian ke bagian lain sangat mudah. Jika hal ini terjadi maka akan menambah potensi keracunan (Raini, 2007).

\section{KESIMPULAN}

1. Asap anti nyamuk kertas bakar dapat mempengaruhi jumlah eritrosit mencit
(Mus musculus L.) berdasarkan analisis sidik ragam pada taraf $1 \%$ karena nilai $\mathrm{F}$ hitung 7,80> F tabel 4,40.

2. Pengaruh asap anti nyamuk kertas bakar yang paling signifikan dalam penurunan jumlah eritrosit mencit (Mus musculus L.) adalah 6 jam paparan karena menghasilkan jumlah penurunan eritrosit lebih besar yaitu dengan rerata $7,88 \times 10^{6} / \mathrm{mL}^{3}$.

\section{DAFTAR PUSTAKA}

Almahdy, A., Dachriyanus, Rosa, M.2014. Uji Efek Teratogen Anti Nyamuk Bakar Yang Mengandung Transfluthrin Terhadap Fetus Mencit Putih.Jurnal Scientia Vol. 4 ISSN :2087-5045. Diakses 18 Desember 2015.

Arobi, I. 2010. Pengaruh Ekstrak Jahe Merah (Zingiber officanale Rosc) Terhadap Perubahan Pelebaran Paru-paru Alveolus Tikus(Rattus norvegicus)yang Terpapar Allethrin.Malang: UIN Maulana Malik Ibrahim. Skripsi.

Djau, R. 2009. Faktor Risiko Kejadian Anemia dan Keracunan Pestisida pada Pekerja Penyemprot Gulma di Kebun Kelapa Sawit PT.Agro Indomas Kab. Seruyan Kalimantan Tengah. Semarang: Program Studi Magister Kesehatan Lingkungan Universitas Diponegoro. Tesis.

Elia, Satiawati, L., dan Rumbajan, J. M. 2015.Kualitas Spermatozoa Tikus Wistar (Rattus norvegicus) Setelah Pemaparan Obat Nyamuk Elektrik Berbahan Aktif Transflutrin.Jurnal $e$ Biomedik (eBm), Vol. 3, Nomor 1.Diakses 1 Desember 2015

Hanafiah, K. A. 2012. Rancangan Percobaaan Teori dan Aplikasi. Jakarta: PT. Raja Grafindo Persada.

Kiswari, R. 2014. Hematologi dan Transfusi. Jakarta: Erlangga.

Marjuki, M. I. 2009. Daya Bunuh Beberapa Obat Nyamuk Bakar Terhadap Kematian Nyamuk Anopheles aconitus.Surakarta: Universitas Muhammadiyah. Skripsi.

Prastiwi, E. P. 2015. Pengaruh Penggunaan Obat Nyamuk Coil Dan Mat Elektrik Terhadap Sel Darah Mencit (Mus 
musculusL).Surakarta: Universitas Muhammadiyah. Skripsi.

Raini, M. 2007. Toksikologi Pestisida dan Penanganan Akibat Keracunan Pestisida. Jakarta: Media Litbang Kesehatan Vol.XVII Nomor 3.

Ramsingh, D. 2010. The Assessment Of The Chronic Toxicity And Carcinogenicity Of Pesticides. Elsevier Inc: Manhattan.

Santoso, L. M. 2014. Panduan Teknik Laboratorium Program Studi Pendidikan Biologi. Inderalaya: FKIP Universitas Sriwijaya

Sundaryono, A. 2011. Uji Aktivitas Senyawa Flavonoid Total Dari Gynura segetum Lour) Terhadap Peningkatan Eritrosit dan Penurunan Leukosit Pada Mencit(Mus musculus). Jurnal Exacta, Vol. IX No.2ISSN 1412-3617. Diakses 30 November 2015.

WHO. 2005. Safety of Pyrethroids of Public Health Use, WHOPES.

Wijayanthi, R. N. 2011. Pengaruh Pemberian Antioksidan Berbagai Vitamin (A, C, dan E) Terhadap Jumlah Eritrosit dan Kadar Hemoglobin Tikus Putih Jantan (Rattus novergicus) yang Dipapar Asap Anti Nyamuk. Malang: Universitas Negeri Malang. Skripsi. 